\title{
COMPETITIVE ABILITY OF BLACK COMMON BEAN GENOTYPES WITH WEEDS
}

\section{Habilidade competitiva de genótipos de feijão comum do grupo "preto" com plantas daninhas}

\author{
Gilcimar Adriano Vogt ${ }^{1}$, Alvadi Antonio Balbinot Junior ${ }^{2}$, \\ Michelangelo Muzell Trezzi ${ }^{3}$, Rogério Luiz Backes ${ }^{4}$, Waldir Nicknich ${ }^{4}$
}

\begin{abstract}
The morpho-physiologic characteristics of common bean plants can affect their competitive ability with weeds. The objective of this work was to evaluate the competitive ability of black bean genotypes with weeds. An experiment was carried out in the 2010/ 11 cropping season in Papanduva, SC, southern Brazil, in order to verify the variability of some plant characteristics among genotypes of common bean. The randomized block design was used, with four replications. Seven cultivars underwent the treatments: BRS Campeiro, CHP 01-238, CHP 01-239, Diamante Negro, BRS Supremo, BRS Valente, IPR Uirapuru, FTS Soberano, IPR Graúna, IPR Tiziu e IAC Diplomata. At 6, 14, 18, 25 and 32 days after emergence (DAE) were evaluated plant height, ground cover by common bean plants, dry biomass of stems and leaves, and grain yield. In the 2011/12 cropping season the same cultivars were grown in the presence or absence of weeds, adopting similar methodology to the 2010/11. The losses of grain yield in black common bean genotypes due to weed interference ranged from $30.8 \%$ to $54.9 \%$. There was a positive correlation between yield reduction promoted by the weed infestation and dry biomass produced by the weeds. In addition, there was a positive correlation between percentage of yield reduction due to the weed infestation and grain yield without weed interference. The characteristics evaluated did not estimate the competitive ability of black common bean genotypes with weeds.
\end{abstract}

Index terms: Phaseolus vulgaris, weed interference, grain yield.

\section{RESUMO}

As características morfofisiológicas de plantas de feijão podem afetar a habilidade competitiva com plantas daninhas. Neste trabalho, objetivou-se avaliar a competitividade de genótipos de feijão do grupo "Preto" com plantas daninhas. Inicialmente, foi conduzido um experimento na safra 2010/11 em Papanduva, SC, para verificar a variabilidade entre genótipos de feijão-preto quanto a algumas características da planta. Foi utilizado o delineamento experimental de blocos casualizados, com quatro repetições. Os tratamentos foram constituídos pelos seguintes genótipos: BRS Campeiro, CHP 01-238, CHP 01-239, Diamante Negro, BRS Supremo, BRS Valente, IPR Uirapuru, FTS Soberano, IPR Graúna, IPR Tiziu e IAC Diplomata. Aos 6, 14, 18, 25 e 32 dias após a emergência (DAE) foram determinadas altura das plantas, cobertura do solo pelas plantas de feijão, massa seca de hastes e folhas e, ao final do ciclo, a produtividade dos grãos. Na safra 2011/12, os mesmos genótipos foram avaliados na presença ou ausência de plantas daninhas, adotando metodologia similar à da safra 2010/11. As perdas de produtividade de grãos dos genótipos de feijão avaliados, em razão da interferência de plantas daninhas, variaram de 30,8 a 54,9\%. Houve correlação positiva entre porcentagem de redução de produtividade em razão da infestação e a massa seca acumulada pelas plantas daninhas. Também houve correlação positiva entre porcentagem de redução de produtividade em função da interferência de plantas daninhas e a produtividade sem infestação. Não foi possível identificar características de plantas que afetam significativamente a habilidade dos genótipos de feijão em competir com plantas daninhas.

Termos para indexação: Phaseolus vulgaris, interferência por plantas daninhas, produtividade de grãos.

(Received in april 26, 2013 and approved in september 6, 2013)

\section{INTRODUCTION}

The black common bean is consumed mainly in the states of Rio de Janeiro, Paraná, Rio Grande do Sul, and Santa Catarina, Brazil. This type of beans and the carioca common bean are the two most consumed groups in Brazil. One relevant factor that limits the yield and depreciates the quality of the grains is the weed interference. This is partly due to the lack of herbicides with high efficiency and low toxicity to the crop. Additionally, the common bean crop has low competitive ability with weeds for water, nutrients and light (PROCOPIO et al., 2004a; CURY et al., 2013). In general, the modern cultivars of common bean have low plant height, about $70 \mathrm{~cm}$, increasing the

\footnotetext{
${ }^{1}$ Empresa de Pesquisa Agropecuária e Extensão Rural de Santa Catarina/EPAGRI - Estação Experimental de Canoinhas - BR 280 - n. 1101 - Campo da Água Verde - Cx.P. 216 - 89460-000 - Canoinhas - SC - Brasil - gilcimar@epagri.sc.gov.br ${ }^{2}$ Empresa Brasileira de Pesquisa Agropecuária/Embrapa Soja - Londrina - PR - Brasil

3Universidade Tecnológica Federal do Paraná/UTFPR - Pato Branco - PR - Brasil

${ }^{4}$ Empresa de Pesquisa Agropecuária e Extensão Rural de Santa Catarina/EPAGRI - Centro de Pesquisa para Agricultura Familiar - Chapecó - SC - Brasil
} 
susceptibility to light competition. Most weed species have characteristics that enable the shading of the common bean plants. This crop has less ability to capture and transform the intercepted light into biomass when compared to soybean (SANTOS et al., 2003). The main reason for the low light gathering ability is the low leaf area of the common bean (PROCOPIO et al., 2004b).

The selection of common bean genotypes with greater competitive ability with weeds is an important strategy to minimize the negative interference of weeds, facilitating the chemical control. The morphophysiological characteristics of crop plants define its competitive ability (BALBINOT JR. et al., 2003a). There is a lack of research to quantify the effects of plant characteristics on the competitive ability of crops (NI et al., 2000; LAMEGO et al., 2005). The characteristics of the crops that contribute to the integrated weed management can promote tolerance to or suppression of weeds. The former is the ability of the crop to maintain its productivity despite the weed interference, and the latter refers to the ability of crops to reduce the growth of weeds (JANNINK et al., 2000).

A limited number of studies were performed to determine the competitiveness of common bean genotypes with weeds. Researches conducted with rice (BALBINOT JR. et al., 2003a; BALBINOT JR. et al., 2003b), wheat (LEMERLE et al., 2001), maize (BEGNA et al., 2001; BALBINOT JR; FLECK, 2005) and soybean (FLECK, VERBEEK; ORCHARD, 2007) indicate that the growth rate is the key factor to increase crop competitiveness with weeds. The early establishment of plants confers advantage in the use of environmental resources. The hypothesis of this research is that there is variability among black common beans genotypes for competitiveness with weeds and it is possible to identify plant characteristics that explain the competitive ability. The objective of this study was to evaluate the competitive ability of black common beans genotypes against weeds.

\section{MATERIAL AND METHODS}

Initially, an experiment was conducted to verify the variability of some characteristics of plants among black common bean genotypes. The experiment was established at 09/11/2010 in the municipality of Papanduva, SC, Brazil. The climate is classified as $\mathrm{Cfb}$, according to the Köppen classification. The soil was identified as Oxisol (EMBRAPA, 1999). The coordinates of the experiment are: 50¹6’37" west, $26^{\circ} 22^{\prime} 15^{\prime \prime}$ south, and $800 \mathrm{~m}$ altitude.
The experimental design was a complete randomized block with four replications. The treatments consisted of common bean genotypes: BRS Campeiro, CHP 01-238, 01-239 CHP, Diamante Negro, BRS Supremo, BRS Valente, IPR Uirapuru, FTS Soberano, IPR Graúna, IPR Tiziu and IAC Diplomata. The plot had four 4-meter long rows spaced at $0.45 \mathrm{~m}$. The two central rows were considered in the evaluations. The experiment was duplicated in order to evaluate the dry biomass of stems and leaves. The experimental area had been managed in no-tillage system for eight years. The common bean genotypes were established after black oat as cover crop, desiccated with glyphosate ( 720 g e.a. ha $\left.{ }^{-1}\right), 15$ days before the sowing. On the day of sowing additional desiccation with glyphosate $\left(360 \mathrm{~g}\right.$ e.a. ha $\left.{ }^{-1}\right)$ was performed. The dose of fertilizer 8-20-20 $\left(\mathrm{N}-\mathrm{P}_{2} \mathrm{O}_{5}-\mathrm{K}_{2} \mathrm{O}\right)$ was $300 \mathrm{~kg} \mathrm{ha}^{-1}$, applied in the rows. The topdressing with $\mathrm{N}$ was not used. Other management practices followed the recommendations for culture techniques (CTSBF, 2010). The weed control was performed with fluazifop-p and fomesafen at doses of 0.20 and $0.25 \mathrm{~kg}$ a.i. ha $^{-1}$, respectively.

At 6, 14, 18, 25 and 32 days after emergence (DAE) these items were determined: (a) plant height in ten plants per plot, by measuring the distance from the soil surface to the apex of the plant; (b) soil coverage by plants, estimated by photos taken at $1.5 \mathrm{~m}$ from the soil surface, which focused on three rows of common bean plants in a single place for all assessments. After that, soil coverage was determined with $\mathrm{SisCob}^{\circledR}$ software; (c) dry biomass of stems, obtained by weighing the stems of ten plants per plot; and (d) dry mass of leaves, obtained by weighing the leaves of ten plants per plot. At the end of development cycle the grain yield by harvest of the two central rows was estimated.

After verifying the variability among common bean genotypes for some characteristics of plants related to competitiveness against weeds, two experiments were conducted in Papanduva, SC, Brazil in the 2011/12 cropping season to verify the interference between common bean genotypes and weeds. The experiments were installed in contiguous areas at 10/11/2011, using the same common bean genotypes and experimental design used in the 2010/11 cropping season. The dose of fertilizer 8-20-20 $\left(\mathrm{N}-\mathrm{P}_{2} \mathrm{O}_{5}-\mathrm{K}_{2} \mathrm{O}\right)$ was $300 \mathrm{~kg} \mathrm{ha}^{-1}$, applied in the rows. The topdressing with $\mathrm{N}$ was not used. Other management practices followed the recommendations for culture techniques (CTSBF, 2010). The first experiment conducted in 2011/12 was maintained without weeds, and the second with weed interference throughout the 
development cycle of the crop. In the first experiment, at 6, 14, 18, 25 and 32 DAE were determined: plant height and soil coverage by common bean plants and at the end of the cycle; and grain yield, using the same methodology used in the 2010/11 cropping season. In the second experiment, at common bean maturity, were determined the grain yield, plant density, and shoot dry biomass of weeds in $1 \mathrm{~m}^{2}$ per plot. The main weed species present in the experiment were: Ipomoea spp., Richardia brasiliensis Gomes (pusley), Cardiospermum halicacabum L. (balloonvine), Bidens pilosa L. (hairy beggarticks), Digitaria horizontalis Willd. (Southern crabgrass) and Urochloa plantaginea Link. (alexandergrass). Based on the yield data with and without weeds we calculated the percentage reduction in yield due to interference.

The data were analyzed using ANOVA and the F test. When an effect of treatments was observed, means were compared by Scott-Knott test, at 5\% probability. For statistical analysis, the Sisvar program (FERREIRA, 2011) was used. Moreover, the linear correlation among variables was determined.

\section{RESULTS AND DISCUSSION}

In the 2010/11 cropping season there was no variation among genotypes for plant height and dry biomass of stems and leaves. However, there were differences among genotypes for soil coverage by common bean plants at 14, 18 and 25 days after emergence (DAE) (Table 1). At 14 DAE, BRS Campeiro demonstrated the greater soil coverage. At 18 and $25 \mathrm{DAE}, \mathrm{BRS}$ Campeiro and CHP 01-239 showed the highest soil coverage. The mean of grain yield observed in the 2010/11 season was $3,269 \mathrm{~kg} \mathrm{ha}^{-1}$, demonstrating that genotypes, environment and management practices were adequate to obtain high yields.

The ability of soil covering by crops at the beginning of the development is an important characteristic to reduce the light availability to weeds that are established in rows or inter-rows (CALLAWAY, 1992; BALBINOT JR. et al., 2003a; LAMEGO et al. 2005). The dense canopy of cultivated plants with high soil covering reduces the quantity and quality of light available to weeds, reducing the net photosynthesis of these plants and, consequently, its competitiveness for water, light and nutrients (BALBINOT JR. et al., 2003b). In soybean, it was possible to observe that genotypes with higher capacity of soil covering at the beginning of the cycle showed greater ability to compete with Bidens spp. and Sida rhombifolia (arrowleaf sida) (BIANCHI, FLECK; FEDERIZZI, 2006). The percentage of soil covering by common bean plants might be estimated by photos or visual analysis and does not require destruction of plants. Thus, this evaluation is very easy in common bean genotypes in order to have information

Table 1 - Soil coverage by black common bean plants and crop yield in different genotypes in the 2010/11 cropping season.

\begin{tabular}{|c|c|c|c|c|}
\hline \multirow{2}{*}{ Genotypes } & \multicolumn{3}{|c|}{ Soil coverage by common bean plants $(\%)$} & \multirow{2}{*}{ Grain yield $\left(\mathrm{kg} \mathrm{ha}^{-1}\right)$} \\
\hline & $14 \mathrm{DAE}^{1}$ & $18 \mathrm{DAE}$ & $25 \mathrm{DAE}$ & \\
\hline BRS Campeiro & $30.2 \mathrm{a}^{2}$ & $52.7 \mathrm{a}$ & $74.0 \mathrm{a}$ & $3,534 \mathrm{a}$ \\
\hline CHP 01-238 & $25.5 \mathrm{~b}$ & $38.2 \mathrm{~b}$ & $56.7 \mathrm{~b}$ & $3,452 \mathrm{a}$ \\
\hline CHP 01-239 & $25.0 \mathrm{~b}$ & $50.0 \mathrm{a}$ & $70.5 \mathrm{a}$ & $2,938 \mathrm{~b}$ \\
\hline Diamante Negro & $23.5 \mathrm{~b}$ & $34.7 \mathrm{~b}$ & $57.7 \mathrm{~b}$ & $3,328 \mathrm{a}$ \\
\hline BRS Supremo & $21.7 \mathrm{~b}$ & $39.7 \mathrm{~b}$ & $62.0 \mathrm{~b}$ & $3,434 \mathrm{a}$ \\
\hline BRS Valente & $21.5 \mathrm{~b}$ & $35.2 \mathrm{~b}$ & $55.7 \mathrm{~b}$ & 3,496 a \\
\hline IPR Uirapuru & $21.5 \mathrm{~b}$ & $34.5 \mathrm{~b}$ & $49.0 \mathrm{~b}$ & $3,636 \mathrm{a}$ \\
\hline FTS Soberano & $21.0 \mathrm{~b}$ & $37.0 \mathrm{~b}$ & $60.5 \mathrm{~b}$ & $3,239 \mathrm{a}$ \\
\hline IPR Graúna & $19.7 \mathrm{~b}$ & $33.7 \mathrm{~b}$ & $49.5 \mathrm{~b}$ & $3,364 \mathrm{a}$ \\
\hline IPR Tiziu & $18.5 \mathrm{~b}$ & $37.7 \mathrm{~b}$ & $55.5 \mathrm{~b}$ & $2,904 \mathrm{~b}$ \\
\hline IAC Diplomata & $16.7 \mathrm{~b}$ & $36.0 \mathrm{~b}$ & $50.0 \mathrm{~b}$ & $2,629 \mathrm{~b}$ \\
\hline Means & 22.2 & 39.1 & 58.3 & 3,269 \\
\hline C.V. $(\%)$ & 20.5 & 18.6 & 15.5 & 12.1 \\
\hline
\end{tabular}

${ }^{1} \mathrm{DAE}=$ days after emergence.

${ }^{2}$ Means followed by the same letters in the column are not different by the Scott-Knott test, $\mathrm{p}<0.05$. 
about their competitiveness with weeds. The differences observed in the 2010/11 cropping season among genotypes for soil covering at 14, 18 and 25 DAE were not verified in the 2011/12 (Table 2). In this way, the environmental condition affects directly the variations among genotypes for ability to cover the soil.

In the 2011/12 cropping season, grain yield without weed interference did not vary among genotypes (Table 3). The average grain yield was $3,676 \mathrm{~kg} \mathrm{ha}^{-1}$, demonstrating the high yield potential of genotypes and appropriate environment for expression of this potential. In the presence of weeds, genotypes that had higher grain yields were CHP 01-238, CHP 01-239, Diamante Negro and IPR Tiziu, evidencing the variability of competitiveness among genotypes. In areas with large seed banks of weeds, genotypes with superior competitive ability can be used to reduce the damage caused by the interference. In research carried out by Carvalho et al. (2011) significant variations in the competitiveness of common bean genotypes with Urochloa decumbens were found.

Table 2 - Soil coverage by black common bean plants in different genotypes, with or without weed interference in the 2011/12 cropping season.

\begin{tabular}{lccc}
\hline \multirow{2}{*}{ Genotype } & \multicolumn{3}{c}{ Soil coverage by common bean plants (\%) } \\
\cline { 2 - 4 } BRS Campeiro & $14 \mathrm{DAE}^{1}$ & $18 \mathrm{DAE}$ & $25 \mathrm{DAE}$ \\
CHP 01-238 & $37.0 \mathrm{a}^{2}$ & Without weed interference & $71.5 \mathrm{a}$ \\
CHP 01-239 & $35.0 \mathrm{a}$ & $49.9 \mathrm{a}$ & $63.0 \mathrm{a}$ \\
Diamante Negro & $34.3 \mathrm{a}$ & $41.2 \mathrm{a}$ & $63.5 \mathrm{a}$ \\
BRS Supremo & $38.0 \mathrm{a}$ & $45.4 \mathrm{a}$ & $62.9 \mathrm{a}$ \\
BRS Valente & $36.8 \mathrm{a}$ & $46.0 \mathrm{a}$ & $66.4 \mathrm{a}$ \\
IPR Uirapuru & $35.4 \mathrm{a}$ & $47.5 \mathrm{a}$ & $65.4 \mathrm{a}$ \\
FTS Soberano & $35.8 \mathrm{a}$ & $47.3 \mathrm{a}$ & $73.0 \mathrm{a}$ \\
IPR Graúna & $33.7 \mathrm{a}$ & $45.8 \mathrm{a}$ & $69.3 \mathrm{a}$ \\
IPR Tiziu & $32.8 \mathrm{a}$ & $46.3 \mathrm{a}$ & $68.2 \mathrm{a}$ \\
IAC Diplomata & $36.8 \mathrm{a}$ & $44.8 \mathrm{a}$ & $64.4 \mathrm{a}$ \\
Means & $35.3 \mathrm{a}$ & $46.5 \mathrm{a}$ & $67.0 \mathrm{a}$ \\
C.V. (\%) & 35.5 & $46.4 \mathrm{a}$ & 66.8 \\
& 7.9 & 46.1 & 12.2 \\
BRS Campeiro & & 8.6 & \\
CHP 01-238 & $33.6 \mathrm{a}$ & With & weed interference \\
CHP 01-239 & $30.7 \mathrm{a}$ & $58.9 \mathrm{a}$ & $85.2 \mathrm{a}$ \\
Diamante Negro & $34.3 \mathrm{a}$ & $51.0 \mathrm{a}$ & $81.5 \mathrm{a}$ \\
BRS Supremo & $34.9 \mathrm{a}$ & $57.0 \mathrm{a}$ & $82.5 \mathrm{a}$ \\
BRS Valente & $32.1 \mathrm{a}$ & $53.9 \mathrm{a}$ & $77.8 \mathrm{a}$ \\
IPR Uirapuru & $33.3 \mathrm{a}$ & $53.5 \mathrm{a}$ & $80.5 \mathrm{a}$ \\
FTS Soberano & $34.7 \mathrm{a}$ & $57.3 \mathrm{a}$ & $82.9 \mathrm{a}$ \\
IPR Graúna & $33.4 \mathrm{a}$ & $60.0 \mathrm{a}$ & $84.8 \mathrm{a}$ \\
IPR Tiziu & $33.2 \mathrm{a}$ & $57.4 \mathrm{a}$ & $77.6 \mathrm{a}$ \\
IAC Diplomata & $31.9 \mathrm{a}$ & $53.3 \mathrm{a}$ & $82.6 \mathrm{a}$ \\
Means & $31.8 \mathrm{a}$ & $44.0 \mathrm{a}$ & $82.2 \mathrm{a}$ \\
C.V. (\%) & 33.0 & $51.5 \mathrm{a}$ & $79.2 \mathrm{a}$ \\
\hline & 14.4 & 55.2 & 81.5 \\
DAE = & 9.9 & 8.8 \\
\hline
\end{tabular}

${ }^{1} \mathrm{DAE}=$ days after emergence.

${ }^{2}$ Means followed by the same letters in the column are not different by the Scott-Knott test, $\mathrm{p}<0.05$.

Ciênc. agrotec., Lavras, v. 37, n. 5, p. 397-403, set./out., 2013 
Table 3 - Grain yield in presence or absence of weed interference and dry biomass of weeds in different black common bean genotypes. 2011/12 cropping season.

\begin{tabular}{lcccc}
\hline Genotypes & $\begin{array}{c}\text { Grain yield without } \\
\text { interference }\end{array}$ & $\begin{array}{c}\text { Grain yield with } \\
\text { interference }\end{array}$ & $\begin{array}{c}\text { Reduction of grain } \\
\text { yield }(\%)\end{array}$ & $\begin{array}{c}\text { Weed biomass } \\
\left(\mathrm{g} \mathrm{m}^{-2}\right)\end{array}$ \\
\hline BRS Campeiro & $\ldots \ldots \ldots \ldots \ldots \mathrm{kg} \mathrm{ha}^{-1} \ldots \ldots \ldots \ldots$. & & $237.2 \mathrm{~b}$ \\
CHP 01-238 & $3,734 \mathrm{a}^{1}$ & $1,720 \mathrm{~b}$ & 46.5 & $191.9 \mathrm{~b}$ \\
CHP 01-239 & $3,687 \mathrm{a}$ & $2,448 \mathrm{a}$ & 44.2 & $145.1 \mathrm{~b}$ \\
Diamante Negro & $3,800 \mathrm{a}$ & $2,585 \mathrm{a}$ & 30.8 & $153.7 \mathrm{~b}$ \\
BRS Supremo & $3,417 \mathrm{a}$ & $2,329 \mathrm{a}$ & 31.3 & $208.7 \mathrm{~b}$ \\
BRS Valente & $3,688 \mathrm{a}$ & $2,065 \mathrm{~b}$ & 43.8 & $153.2 \mathrm{~b}$ \\
IPR Uirapuru & $3,684 \mathrm{a}$ & $1,751 \mathrm{~b}$ & 52.4 & $401.3 \mathrm{a}$ \\
FTS Soberano & $4,190 \mathrm{a}$ & $1,895 \mathrm{~b}$ & 54.9 & $223.1 \mathrm{~b}$ \\
IPR Graúna & $3,782 \mathrm{a}$ & $2,047 \mathrm{~b}$ & 43.0 & $162.9 \mathrm{~b}$ \\
IPR Tiziu & $3,491 \mathrm{a}$ & $2,033 \mathrm{~b}$ & 41.1 & $169.1 \mathrm{~b}$ \\
IAC Diplomata & $3,710 \mathrm{a}$ & $2,426 \mathrm{a}$ & 33.7 & $172.7 \mathrm{~b}$ \\
Means & $3,255 \mathrm{a}$ & $1,798 \mathrm{~b}$ & 44.8 & 201.7 \\
C.V. (\%) & 3,676 & 2,100 & 40.6 & 50.7 \\
\hline
\end{tabular}

${ }^{1}$ Means followed by the same letters in the column are not different by the Scott-Knott test, $\mathrm{p}<0.05$.

It was expected that the genotype BRS Campeiro presented high productivity in the presence of weeds and small percentage of reduction in grain yield due to the weed interference, because it showed a high soil covering rate in the 2010/11 cropping season (Table 1), but this was not observed (Table 3).

The average of reduction in grain yield due to weed interference was $42.8 \%$, or $1,576 \mathrm{~kg} \mathrm{ha}^{-1}$ (Table 3), demonstrating the high damage of weeds. This occurred due to the high density of weeds in the experimental area, an average of 101 and 17 plants $\mathrm{m}^{-2}$ monocots and dicots, respectively, evaluated at $14 \mathrm{DAE}$, and due to low competitive ability of common bean (PROCOPIO et al., 2004a; CURY et al., 2013).

Positive correlation was observed between yield of common beans without weed interference and reduction of yield imposed by interference (Figure 1). Thus, some characteristics of plants which provide higher grain yields negatively affect the competitive ability with weeds. In common beans, lower allocation of photo assimilates in roots and compact canopy that allows light and pesticides penetration in the canopy are important characteristics to improve yield, but at the same time they can reduce competitiveness against weeds. On the other hand, according to Balbinot et al (2003), in rice there is no relationship between grain yield without weeds and reduction of yield due to interference.

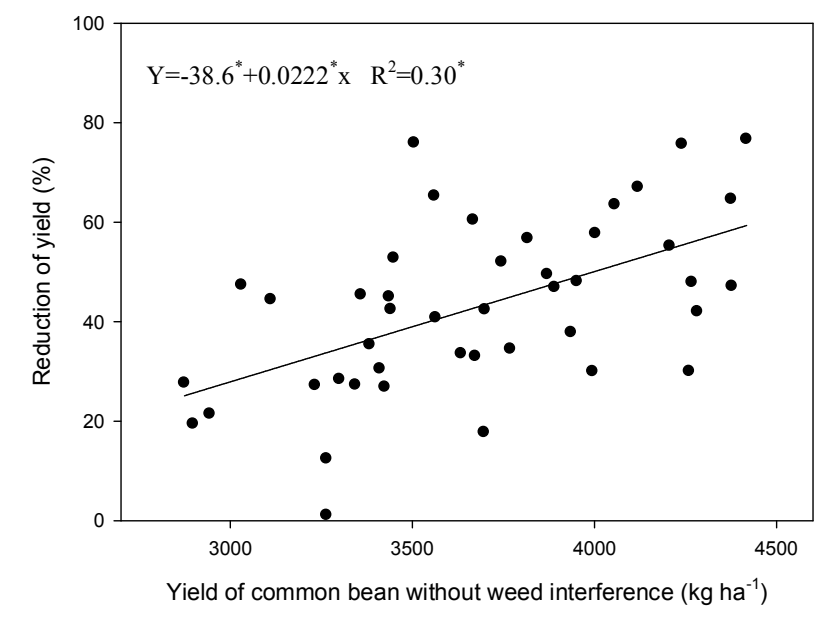

Figure 1 - Relationship between yield of common bean without weed interference, and reduction of yield due to weed interference. $2011 / 12$ cropping season. * Significant $\mathrm{p}<0.05$.

The higher dry biomass of weeds at harvest of common bean was observed in the IPR Uirapuru, and this genotype showed the highest reduction of grain yield due 
to the interference (Table 3). It was possible to observe a positive correlation between the biomass of weeds and reduction of yield imposed by weeds (Figure 2). The genotypes that had lower yield losses due to interference tended to reduce the biomass production by weeds. In this sense, the competitive ability of black common bean genotypes was more related to the ability to suppress weeds than to tolerate their presence, as discussed by Jannink et al. (2000). The ability to suppress the growth of weeds is relevant to reduce the weed seed bank in the soil.

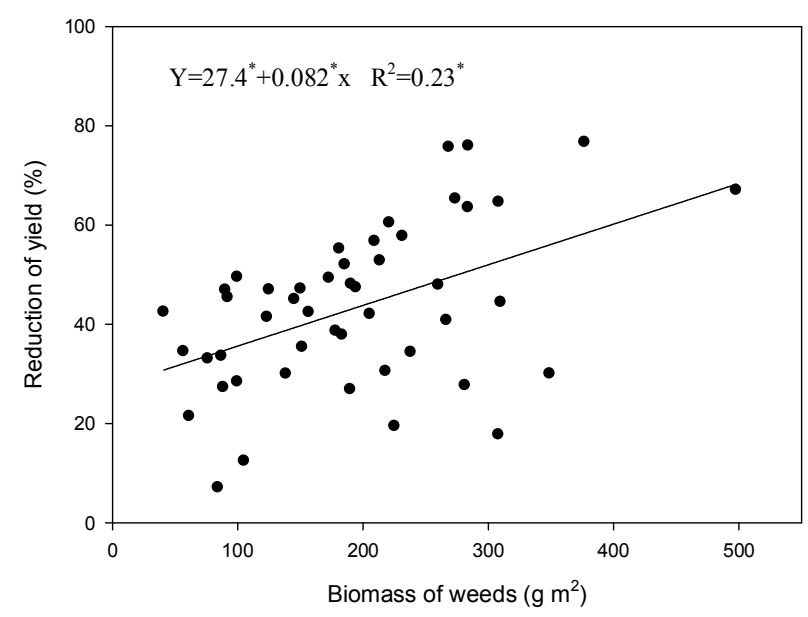

Figure 2 - Relationship between dry biomass of weeds and reduction of yield due to weed interference. 2011/12 cropping season. $*$ Significant $\mathrm{p}<0.05$.

Unlike what was observed in other studies conducted with rice (BALBINOT JR. et al., 2003a), corn (BEGNA et al., 2001), soybean (BIANCHI et al., 2006) and wheat (LEMERLE et al., 2001), the percentage of soil coverage by common bean plants and the plant height did not estimate consistently the competitive ability of black common bean genotypes. Probably roots characteristics of common bean genotypes influence the competitiveness against weeds, as discussed by Cury et al. (2013).

\section{CONCLUSIONS}

The losses of grain yield in black common bean genotypes due to weed interference ranged from $30.8 \%$ to $54.9 \%$, while the genotypes that showed the lowest yield losses also demonstrated greater suppression of weed growth.

There was a positive correlation between the grain yield potential in black common bean genotypes and the reduction of yield due to weed interference.
Characteristics of plants in black common bean genotypes consistently related to competitiveness with weeds were not identified.

\section{REFERENCES}

BALBINOT JR., A.A. et al. Competitividade de cultivares de arroz irrigado com cultivar simuladora de arrozvermelho. Pesquisa Agropecuária Brasileira, Brasília, v.38, n.1, p.53-59, $2003 a$.

BALBINOT JR., A.A. et al. Características de arroz e a habilidade competitiva com plantas daninhas. Planta Daninha, Viçosa, v.21, n.2, p.165-174, 2003 b.

BALBINOT JR., A.A.; FLECK, N.G. Manejo de plantas daninhas na cultura de milho em função do arranjo espacial de plantas e características dos genótipos. Ciência Rural, Santa Maria, v.35, n.1, p.245-252, 2005.

BEGNA, S.H. et al. Morphology and yield response to weed pressure by corn hybrids differing in canopy architecture. European Journal of Agronomy, Amsterdam, v.14, p.293-302, 2001.

BIANCHI, M.A.; FLECK, N.G.; FEDERIZZI, L.C. Características de plantas de soja que conferem habilidade competitiva com plantas daninhas. Bragantia, Campinas, v.65, n.4, p. 623-632, 2006.

CALLAWAY, M.B. A compendium of crop varietal tolerance to weeds. American Journal of Alternative Agriculture, Greenbelt, v.7, n.4, p.169-180, 1992.

CARVALHO, A.J. de et al. Efeito da época de semeadura de Brachiaria decumbens e de dessecantes em pré-colheita sobre o rendimento de grãos do feijoeiro e a biomassa forrageira em cultivo consorciado. Ciência e Agrotecnologia, Lavras, v.35, n.5, p.893-899, 2011.

CURY, J.P. et al. Eficiência nutricional de cultivares de feijão em competição com plantas daninhas. Planta Daninha, Viçosa, v.31, n.1, p.79-88, 2013.

COMISSÃO TÉCNICA SUL-BRASILEIRA DE FEIJÃO. CTSBF. Informações técnicas para o cultivo do feijão na Região Sul brasileira 2009. Florianópolis: Epagri, 2010. $164 \mathrm{p}$. 
EMPRESADE PESQUISAAGROPECUARIAEMBRAPA. Sistema brasileiro de classificação de solos. Brasília: Embrapa Produção de Informação/Rio de Janeiro: Embrapa Solos, 1999. 412 p.

FERREIRA, D.F. Sisvar: a computer statistical analysis system. Ciência e Agrotecnologia, Lavras, v.35, n.6, p.1039 1042, 2011.

FLECK, N.G. et al. Resposta de cultivares de soja à competição com cultivar simuladora da infestação de plantas concorrentes. Scientia Agraria, Curitiba, v.8, n.3, p.213-218, 2007.

JANNINK, J.L. et al. Index selection for weed suppressive ability in soybean. Crop Science, Madison, v.40, n.4, p.1087-1094, 2000.

LAMEGO, F.P. et al. Tolerância à interferência de plantas competidoras e habilidade de supressão por cultivares de soja - I. Resposta de variáveis de crescimento. Planta Daninha, Viçosa, v.23, n.3, p.405-414, 2005.
LEMERLE, D.; VERBEEK, B.; ORCHARD, B. Ranking the ability of wheat varieties to compete with Lolium rigidum. Weed Research, Oxford, v.41, p.197-209, 2001.

NI, H. et al. Oryza sativa plant traits conferring competitive ability against weeds. Weed Science, Lawrence, v.48, n.2, p.200-204, 2000.

PROCÓPIO, S.O. et al. Ponto de murcha permanente de soja, feijão e plantas daninhas. Planta Daninha, Viçosa, v.22, n.1, p.35-41, 2004a.

PROCÓPIO, S.O. et al. Características fisiológicas das culturas de soja e feijão e de três espécies de plantas daninhas. Planta Daninha, Viçosa, v.22, n.2, p.211-216, 2004b.

SANTOS, J.B. et al. Captação e aproveitamento da radiação solar pelas culturas da soja e do feijão e por plantas daninhas. Bragantia, Campinas, v.62, n.1, p.147$153,2003$. 